\title{
Parecer da Comissão de Acumulação de Cargos
}

\author{
Processo $n^{\circ} 14.752-63$ - Nào \\ licita a acumulação de trìs cargos \\ públicos.
}

\section{PROCESSO N $\quad 14.752-63$}

Em hipótese alguma é licita a acumulação de três cargos públicoss.

E' legitimo o exercício cumuiativo dos cargos de Advogado de Ofício junto ao Juizado de Dreito da $5^{\prime}$ Vara da Comarca de Aracaju, e de Professor Catedrático de. Direito Romano, da Faculdade de Direito de Sergipe.

Igualmente licito o exeicicio d, aludido cargo de magistério, com a percepção cumulativa dos proventos de disponibilidade, n) cargo de Proiessor Catedrático de Latim, úo Colégı Es tadual de Sergipe.

\section{P.ARECER}

Cogita-se, no presente processo, da nomeação de Alberto Braganç̧a de Azevedo, Advogado de ofícis junto ao Juizado de Direito da 5 Vara da Comarca de Aracaju e Professo: Cairdático de Latim, $\mathrm{rm}$ disponibiliclade, do Colégio Estadual de Sergipe, pıra exercer o cargo de Professur Citét:ático de Direito Romano, dia Facuidade de Direito daquele Estado.

2. Atendendo a diligenzía cieterminada por esta comissão, foi anexada ao processo a decla:açẵo de opção do interessado, em virtude de "nãc ser legalmente viável a detenção de excrcicio ou de vantagers financeiras de três cargos públicos".

3. Declara o interessado que, "após chamado ao magisterio feder:ıl, quando, evidentemente, se caracterizaria a inviabilidade apontada", "declararia opção por uma das duas remunerações supranomeadas, na vida estadual":

4. Dêsse modo, cumpre-nos examinar as duas situaçồ.s que poderiam advir: $1^{\circ}$, a acumulaŗăo dos carg.ss de Advogado de oficio junto ao Juizado de Direito e de Prulesisor Cátearático de Direito Risman, da Faculdade de Direito de Sergipe; e $2^{\circ}$, o exercicio dêste último, com a percepção cumulativa dos proventos de tisponibilidade no cargo de Professor $\mathrm{Ca}$ tedrático de Latim do Colégio Estadual de Sergipe.

5. Na primeira hipóiesc, em se tratando de execcício concomitante de un cargo técnico, com outro de magistério, a situaçăo se enquadrn, em principio, em uma das exce,çôes à regra geral que proibe a acumulação de quaisquer cargos públicus, inscrita no artigo 185 da Constituição Federal.

6. O requisito da correlação de inatérias indispensável à pe:missibilidade da acumulação em aprêço, è de existência inquestionável, visto como o Direito Rcmano mantém estreita e reciproca relação com as atividades de Advogado - Bacharel em Dire:to de cujo curriculo de formaşâo profissional faz parte.

7. A compatibilidade horáría está, por sua vez, demonst:ada na certidão expedida, em 25 de setembro último, pela Faculdade de Direito de Sergipe, na qual se declara prestar o interessado o numero de horas de trabalho exigido a todos os membros do magistério, no periodo de 8 às 12 horas, diàriamente, e no atestado firmado pelo MM. Juiz de Direito da $5^{\circ}$ V'ara da Comarca de Aracaju, em que se 
comprova sua não obrigatoriedade de assinatura de ponto, nem de sujeição a horário, embora, "sponte sua" compareça àquele Juizado às segundas, quartas e sextas-feiras, apćs as aulas.

8. Na segunda hipótese, de exercicio do aludido cargo de magistério, com a percepção cumulativa dos proventos de disponibilidade no cargo de Professor Catedrático de Latim do Colégio Estadual de Sergipe, a situação é regida pelo disposto no artigo 10 do Decreto $\mathrm{n}^{2} 35.956$, de 2 de agôsto de 1954, verbis.

"A acumulação de proventos de inatividade, resultante de aposentadoria ou disponibilidade, ou dêstes $\mathrm{com}$ a retribuição de atividade, só é permitida quando proveniente de cargos acumuláveis, ressalvados os casos decorrentes de disposto no art. 24 do Ato das Disposições Constitucionais Transitórias".

9. Legitima "é, também, nesse caso, a acumulação, por se tratar de dois cargos de magistério, em que as disciplinas mantêm estreita e reciproca relação, isto porque

"o Latim é, sem dúvida, o indispensável instrumento do Professor de Direito Romano, que deve estar em condiçães de lidar $\operatorname{com}$ os textos e interpretá-los",

e, ainda, porque,

"se no curso do ensino médio o professor de Latim é obrigado a recorrer ao Direito Romano, afortiori compreende-se que, num curso superior, verbi gratia, a correlação deva ser muito mais acentuada",

como já esclareceu esta Comissão no processo $\mathrm{n}^{\circ}$ 10.096-56.

10. A compatibilidade horária é, no caso, de verificação desnecessária, face à condição de disponivel do interessado, no cargo de Professor Catedrático de Latim do Colégio Estadual de Sergipe.

11. Ante o exposto, opinamos por que se considere licita qualquer das duas hipóteses que poderá advir com a nomeação de Alberto Bragança de Azevedo, desde que faça, na época oportuna, a opção por uma das situcções estaduais.

C.A.C., em 22 de novembro de 1963. - (a.) Zola Maria Fraga, Relator. - José Medeiros. - Célio Fonseca. - Aluisio Xavier Moreira. Corsindio Monteiro da Silva. - Alvaro da Costa Lins Júnio:.

Submeto, nos têrmos do $\S 3^{\circ}$ do art. 15, do Decreto $\mathrm{n}^{\circ} 35.956$, de 2 de agôsto de 1954, o presente parecer à aprovação do $\mathrm{Sr}$. Diretor-Geral do D.A.S.P.

Brasilia, em 25 de novembro de 1963 - José Medelros, Presidente da Comissão de Acumulação de Cargos. Aprovo, André Carrazzoni - 27-11-63. 